\title{
Stroke Unit : Does it make a difference? Assessment of the early effectiveness of a Stroke Unit in improving functional state in Dr. Cipto Mangunkusumo Hospital
}

\author{
Al Rasyid, M.Kurniawan Saleh, Jusuf Misbach
}

\begin{abstract}
Abstrak
Unit Stroke (US) telah terbukti sangat baik dalam peawatan pasien stroke.Penelitian US pada tahun 1990 menunjukkan hasil dengan peningkatan rata-rata kehidupan dan perbaikan status fungsional penderita dan menurunkan hari perawatan pasien.Di Indonesia US masih baru sehingga penelitian tentang tatalaksana perawatan di US sangat diperlukan.Penelitian ini dilakukan untuk evaluasi manfaat US sebagai perawatan pasien stroke khususnya perbaikan status fungsional pasien dibandingkan perawatan pasien di Sudut Stroke Bangsal Umum Neurologi.Hasil penelitian menunjukan perbaikan status fungsional stroke (Skor NIHSS) baik di US maupun di Sudut Stroke Bangsal Neurologi Umum.Data memperlihatkan penurunan nilai NIHSS yaitu 17,35 menjadi 5,31 sedangkan di Sudut stroke 13,83 menjadi 8,87. Dengan menggunakan Independent t-test,penurunan NIHSS di US signifikan dibandingkan sudut stroke di bangsal neurologi umum. (Med J Indones 2006; 15:30-3)
\end{abstract}

\begin{abstract}
Abstact
Stroke unit has been believed as the best institutional care for stroke patients. Recent researches in 1990s indicated that stroke units can produce increasing survival rate and improving the functional state of the patients which can reduce the need for institutional care after stroke. In Indonesia, stroke unit is still new. Because stroke unit has educational role beside its clinical importance, the research about stroke unit especially in its value in managing stroke patients in Indonesia is needed. This study was evaluated the effectiveness of stroke unit care in managing stroke patients especially in improving the functional state of the patients in compared with conventional care of stroke corner in general neurology ward. This study indicated that both stroke unit (SU) and stroke corner in general neurology ward (SC) shows reduction in NIHSS score. In Stoke Unit, the reduction of NIHSS was 17.35 to 5.31 while in Neurology ward from 13.83 to 8.87. Using independent $t$-test, the reduction of NIHSS in stroke unit is more significance compared with stroke corner in general neurology ward ( $p=0,000)$. (Med J Indones 2006; 15:30-3)
\end{abstract}

Keywords: Stroke Unit, General Neurology Ward, NIHSS

Stroke is both common and serious. It has been estimated that in 1990s stroke caused 4.4 million deaths per year worldwide. It is the third leading cause of death in most countries, which half of the patients will have died or remain physically dependent. Some reports now show a stable or increasing incidence of stroke. The incidence increased with age, and the consequence of demographic changes could result in stroke becoming an increasing cause of mortality and morbidity. In Indonesia, stroke is a

Department of Neurology, Faculty of Medicine University of Indonesia/Dr. Cipto Mangunkusumo Hospital, Jakarta, Indonesia major public health problem associated with high mortality, disability, and financial cost. ${ }^{1,2}$

What is the most effective treatment strategy for stroke patients? The answer to this question is important, because stroke is frequent, lethal, and expensive. ${ }^{3}$ The last five to ten years have seen an intensive research effort to find novel treatments for acute stroke with many more large trials of thrombolytic and neuroprotective agents. Unfortunately, none of these treatments have proven effective enough to recommend routine use in acute stroke. Perhaps the most significant advance in stroke management therefore has not been pharmacological, but concerns the process of care for stroke patients, with convincing evidence that changing the approach to the way stroke patients are managed 
has a beneficial impact on both mortality and morbidity. The concept of organized care on geographicallydefined units has given rise to a more disease-specific approach to the management of stroke. In 1993, results from all existing randomized controlled trials comparing the outcome of patients managed in defined stroke units with outcomes from conventional settings of care were examined in a meta-analysis. This showed that care on a stroke unit reduced mortality by $28 \%$ and also reduced the risk of patients requiring institutionalized care at a median of 12 months after stroke. ${ }^{4}$ A recent systematic review of the randomized trials that have compared organized inpatient (stroke unit) care with contemporary conventional care has indicated that stroke patients who are managed in an organized (stroke unit) setting are less likely to die, remain physically dependent, or require long-term institutional care. ${ }^{5}$ Randomized controlled trials also have shown the effectiveness of stroke unit in improving survival and functional state of the patients during the first 5 year and 10 year onset. ${ }^{6,7}$ In short term care, it has been proven that stroke unit benefited the patients especially in improving their functional outcomes besides survival benefits. 8,9

According to those researches, establishing a hospital stroke unit (SU) is one promising new therapeutic approach. In Indonesia, a stroke unit was first started in 1994 in Dr. Cipto Mangunkusumo Central Hospital. And this study was performed to test the effectiveness of stroke unit compared to general neurology ward especially in improving the functional state of the patients using NIHSS score as the parameter.

\section{METHODS}

Dr. Cipto Mangunkusumo Central Hospital in Jakarta is a national hospital which serves not only the population in Jakarta but also the referred patients from all over Indonesia. The trial involved stroke patients from all age groups admitted to the hospital of symptoms of a stroke. Between January 1, 2003, and December 31, 2003, 489 patients were admitted to the hospital and included in the study.

Stroke was defined according to World Health Organization criteria as a vascular lesion of the brain resulting in a neurological deficit persisting for $\geq 24$ hours or resulting in death of the individual. Patients with intracerebral hemorrhage or prior stroke(s) were not excluded. Patients with primary subarachnoid hemorrhage or subdural hematoma were excluded from the study.

Once admitted, patients were allocated to either a SU or a SC according to their own choice which resulted in stroke unit (SU) group $(n=226)$ and stroke corner in general neurology ward (SC) group $(\mathrm{n}=263)$.

\section{Stroke Unit}

Stroke unit in the hospital has 14 bed with air conditioned room and monitoring facilities such as ECG monitor, bladder training monitor and syring pump. A standard examination was performed including neurological assessment, blood test, electrocardiography, and computed tomography (CT) of the brain within 2 hours after admittance. If an ischemic stroke was suspected after clinical and CT evaluation, acetyl acid $160 \mathrm{mg}$, was immediately administered per os. As early as possible, the patient was mobilized, often within the first hours after admittance to the hospital. The routine of mobilization of patients with hemorrhages was the same as for those with ischemic strokes. Parenteral isoosmolar fluid was administered routinely the first 24 hours. Hyperglycemia was treated with insulin when serum glucose was $\geq 150 \mathrm{~g} / \mathrm{dL}$. Fever was treated with antipyretics (paracetamol, 500 $\mathrm{mg}$ tablet) when temperature was $\geq 38^{\circ} \mathrm{C}$. Antihypertensive treatment was not initiated the first week except for markedly elevated blood pressure. If cardioembolic stroke was suspected, a cardiologist was consulted and eventually anticoagulation was initiated. The staff was multidisciplinary with neurologists, well-trained nurses for stroke care with nurse/patient ratio $1: 2$, physiotherapists, occupational therapists and speech-therapists. A stroke team met weekly for evaluation of the progress and to plan further treatment for each patient. The nurses were specially trained to detect and avoid complications.

\section{Stroke Corner in General Neurology Ward}

The hospital has neurology department with three wards. Stroke patients were admitted to two wards, depend on sex. Patients treated within the stroke corner in general neurology wards (SC) were given conventional and good medical treatment as usually given for stroke patients. As in the SU, a CT scan was requested but can be delayed although in emergency setting. Patients with ischemic strokes were mobilized and so were the hemorrhagic patients. Aspirin was 
given if the CT scan did not reveal a bleeding. There was routine of giving antipyretics or parenteral isoosmolar fluids, as in the SU. Antihypertensive treatment was not initiated the first week except for markedly elevated blood pressure. Anticoagulation was started when a possible cardiogenic embolic source was detected. Patients were offered physiotherapy, occupational therapy if needed, and evaluation of a general practitioner who is taking the first year of neurology residency.

\section{Outcome and Measures}

The primary outcomes were functional state using National Institute of Healtlh Stroke Scale (NIHSS) score. Follow-up assessments were performed in the hospital on day 1 and day of discharge were performed by the primary investigator. All clinical assessments except at admittance were performed by the primary investigator. He performed the score the next day and also knowing the score at admission.

\section{Statistical analysis}

Statistical analysis was performed using the software package SPSS for Windows 11.0. Differences between the groups in outcome are presented in mean difference and odds ratio with 95 confidence intervals, which were analyzed by independent t-test. $x^{2}$ statistics and independent t-test were used when appropriate to determine significance of difference among background variables compared. Patients are studied on intention-to-treat basis. Even though data were collected retrospectively, the sampling was on the basis of an input variable (treatment) and hence produces a cohort (prospective) study.

\section{RESULTS}

A total of 489 patients (147 women and 245 men) were included in our study, of whom 226 were treated in the SU and 263 were treated in the SC. The mean age was $59.83 \pm 11.75$ years. Of these patients, 369 had suffered cerebral infarctions, and 120 had suffered cerebral hemorrhages. There were no significant differences $(\mathrm{P}>0.05)$ between the two groups with regard to sex, age, degree of education, time of initial treatment, or previous history of strokes. There were also no significance difference between the two groups according to history of diabetes mellitus and history of cardiac disease. But, there were significance difference in history of hypertension, smoking habits, and type of stroke between SU groups and SC groups. Patients in SC were predominantly hemorrhagic, have more hypertensive disease and history of smoking compared with the SU patients. Those differences maybe caused be different background of social and economy of both group. At the time of admission, there was no statistically significant difference between the two groups with regard to NIHSS scores (SU 17.35 \pm 10.44 , GW 13.83 $\pm 8.61, \mathrm{p}=0.23$ ).

Table 1. Characteristics of the Patients

\begin{tabular}{llll}
\hline Characteristics & $\begin{array}{l}\text { Stroke Unit } \\
(\mathrm{n}=226)\end{array}$ & $\begin{array}{l}\text { Stroke Corner } \\
(\mathrm{n}=263)\end{array}$ & $\boldsymbol{P}$ \\
\hline Mean age, year (SD) & $62.3(11.4)$ & $57.7(11.6)$ & 0.43 \\
Male sex & $135(59.7 \%)$ & $170(64.6 \%)$ & 0.30 \\
Female sex & $91(41.2 \%)$ & $93(35.4 \%)$ & 0.30 \\
Prior medical history & & & \\
Prior stroke & $89(39.3 \%)$ & $81(30.8 \%)$ & 0.57 \\
Hypertension & $78(34.5 \%)$ & $187(71.1 \%)$ & 0.00 \\
Diabetes mellitus & $39(17.3 \%)$ & $35(13.3 \%)$ & 0.08 \\
Cardiac disease & $14(6.2 \%)$ & $21(8.1 \%)$ & 0.06 \\
$\quad \begin{array}{l}\text { Smoking history } \\
\text { Onset of hospitaliza- }\end{array}$ & $23(10.22 \%)$ & $73(27.8 \%)$ & 0.00 \\
$\quad$ tion, hours & & 33.43 & 0.16 \\
Hemorrhage on CT & $29(12.8 \%)$ & $91(34.63 \%)$ & 0.00 \\
\hline
\end{tabular}

The NIHSS score were then calculated again when the patients discharged from hospital. The final NIHSS score of SU patients were $5.31 \pm 5.42$ and $8.87 \pm 6.38$ for stroke corner patients. According to the initial and final NIHSS score, the changes of NIHSS score was calculated. There were significant differences in terms of the changes in NIHSS scores, $12.04 \pm 10.62$ for SU patients and $4.91 \pm 3.86$ dor SC patients with mean difference $7.13, \mathrm{p}=0.000$, CI 5.66;8.56)

Table 2. Length of hospitalization and NIHSS Score

\begin{tabular}{lcccc}
\hline & $\mathrm{SU}$ & $\mathrm{SC}$ & $95 \% \mathrm{CI}$ & $P$ \\
\hline $\begin{array}{l}\text { Length of } \\
\text { care, day }\end{array}$ & 9.7 & 10.1 & $-1.95 ; 1.42$ & 0.761 \\
& & & & \\
NIHSS score & & & & \\
& & & & \\
Initial NIHSS & 17.3 & 13.8 & $1.82 ; 5.21$ & 0.023 \\
& $(10.4)$ & $(8.6)$ & & \\
Final NIHSS & 5.3 & 8.8 & $-4.61 ;-2.61$ & 0.000 \\
& $(5.4)$ & $(6.3)$ & & \\
NIHSS changes & 12.04 & 4.91 & $5.66 ; 8.56$ & 0.000 \\
& $(10.6)$ & $(5.8)$ & & \\
\hline
\end{tabular}




\section{DISCUSSION}

Cerebrovascular diseases (CVD) have a significant impact on human health and are of great concern to society in all countries. Over the past half century, the most promising developments in the care given to stroke patients have focused on treatment techniques, but not on new medicines. SU is an approach to the management of acute stroke patients, which emphasizes active intervention to reduce both morbidity and mortality. Treatment in SU is more effective than the conventional treatment in general ward in increasing the survival rate and improving functional state. ${ }^{3,4}$

This study confirmed the effectiveness of SU to enhance functional state among stroke patients even among unselected stroke patients with a short length of stay. This is the first stroke unit controlled trial in Indonesia and the first that focused on improvement of functional state using NIHSS score as a parameter. Patients entering this study presented with an acute stroke, and the diagnosis was confirmed during the hospitalization. Some previous trials found $\mathrm{SU}$ beneficial in increasing survival in a short-term follow-up. The trials that focused on improvement of functional state were using long-term evaluation (seven months, one year, five years and ten years) and using Barthel Index of Activity Daily Living. ${ }^{5,7,8}$

Our study demonstrates that, compared with treatment in SC, treatment in SU can significantly decrease the time needed to return to normal daily life, reduce permanent impairments and disabilities resulting from the stroke, and enhance the ability to resume normal social roles. Furthermore, our study suggests that the efficacy of SU is consistently higher than in SC, regardless of age, sex, time of initial treatment or prior medical history.

Which are the possible explanations of the improvement of functional state among patients treated in the SU? Because we did not isolate specific parts of the treatment package, we are still uncertain about which components are most important. We believe, as other investigators do, that the effects are probably caused by minimal secondary complication and a more coordinated and focused program of rehabilitation involving patients and caregivers. This program may well allow caregivers to better assist with the rehabilitation process to continue therapeutic strategies beyond formal therapy sessions and thereby allow more patients to achieve independence. Almost all of the stroke units used a more intensive physiotherapy and occupational therapy input than conventional care. In addition, less tangible factors, such as the level of patient motivation and morale, may have been improved in the stroke unit setting. Observational studies comparing patient activity within stroke unit and the general ward settings have indicated that stroke unit patients spend more of their time in more appropriate and purposeful activity. ${ }^{4,5,10}$

In conclusion, instead of limitations of available data and methodology, our findings support previous findings of the improvement of functional state of the patients treated in stroke unit. This beneficial effect can be confirmed in a short period of care.

\section{REFERENCES}

1. Langhorne P, Dennis M. Stroke Unit : an evidence based approach. BMJ Books 1998

2. Ronning M, Guldvog B. Stroke Unit versus general medical wards, I : twelve and eighteen month survival, a randomized, controlled trial. Stroke 1998;29:58-62.

3. Rui Hua MA, Yong-jun W, Hui Qu, Zhong-hua Y. Assessment of the early effectiveness of a stroke unit in comparison to the general ward. China Med J 2004;117 (6):852-5

4. Sinha A, Warburton EA. The evolution of stroke unitstowards a more intensive approach? QJ Med 2000;93:633-8

5. The Stroke Unit Trialists' Collaboration. How Do Stroke Units Improve Patient Outcome ? Collaborative systematic review of the randomised trials. Stroke 1997;28:2139-49.

6. Indredavik B, Bakke F, Slørdahl S. A, Rokseth R, Håheim L. Stroke unit treatment improves long-term quality of life: a randomized controlled trial. Stroke 1998;29:895- 899.

7. Indredavik B, Bakke F, Slørdahl S. A, Rokseth R, Håheim L. Stroke Unit Treatment 10-year follow-up. Stroke 1999;30:1524-7.

8. Ronning M, Guldvog B. Stroke Unit versus general medical wards, II: Neurological deficits and activities of daily living, a quasi-randomized controlled trial. Stroke 1998;29:586-90

9. Stavem K, Ronning M. Survival of unselected stroke patients in a stroke unit compared with conventional care. QJ Med 2002;95:143-52.

10. Lincoln NB, Willis D, Philips SA, Juby LC, Berman P. Comparison of rehabilitation practice on hospital wards for stroke patients. Stroke 1996;27:18-33. 